УДК 656.222.3

\title{
АНАЛІЗ ТА УДОСКОНАЛЕННЯ ІСНУЮЧИХ ПІДХОДІВ ДО РАЦІОНАЛЬНОГО РОЗПОДІЛУ ТРАНСПОРТНИХ РЕСУРСІВ
}

Д-р техн. наук Д.В. Ломотько, канд. техн. наук А.О. Ковальов, асист. О.В. Ковальова

\section{АНАЛИЗ И УСОВЕРШЕНСТВОВАНИЕ СУЩЕСТВУЮЩИХ ПОДХОДОВ К РАЦИОНАЛЬНОМУ РАСПРЕДЕЛЕНИЮ ТРАНСПОРТНЫХ РЕСУРСОВ}

Д-р техн. наук Д.В. Ломотько, канд. техн. наук А.А. Ковалев, ассист. О.В. Ковалёва

\section{ANALYSIS AND IMPROVEMENT OF EXISTING APPROACHES TO THE RATIONAL DISTRIBUTION OF TRANSPORT RESOURCES}

Doct. of techn. sciences D. Lomotko, kand. of techn. sciences A. Kovalov, assistant O. Kovalova

У статті запропоновані підходи до удосконалення автоматизованої системи для забезпечення вантажсовасників транспортними засобами відповідно до їх заявок. Наведений метод виконання заявок, а саме розподіл рухомого складу відповідного технічного стану під навантаження, дозволяє забезпечити вантажовласників необхідною кількістю транспортних ресурсів з урахуванням перевезення певної номенклатури вантажу.

Ключові слова: розподіл, транспортні ресурси, забезпечення вагонами, технічний стан, вантаж.

В статье предложены подходы к совершенствованию автоматизированной системы для обеспечения грузовладельиев транспортными средствами в соответствии с их заявками. Приведенный метод выполнения заявок, а именно распределение подвижного состава соответствующего технического состояния под погрузку, позволяет обеспечить грузовладельцев необходимым количеством транспортных ресурсов с учетом перевозки определенной номенклатуры груза.

Ключевые слова: распределение, транспортные ресурсы, обеспечение вагонами, техническое состояние, груз.

The paper proposed approaches for improving automated systems for cargo vehicles according to their applications using logistic methods. In the current system orders for transportation of cargo owner is unable to specify additional requirements necessary technical condition of rolling stock provided to the load, so there is a situation of possible errors in distribution.

The method performance applications, such as distribution of the rolling stock related technical state of loading, allows for the necessary number of cargo transport resources, given the range of a cargo transportation with minimum costs and maximum preservation possibility cargo.

Keywords: distribution, transportation resources, wagons, technical condition, cargo.

Вступ. Створення нових та удосконалення існуючих автоматизованих систем оперативного керування перевезеннями та автоматизованих систем керування вагонними парками залізниць $€$ на сьогоднішній день одним з найактуальніших питань, пов'язаних із прийняттям ефективних регулювальних заходів щодо раціонального використання наявних транспортних засобів різного технічного стану, що забезпечать підвищення ефективності роботи $з$ парком вантажних вагонів.

Постановка проблеми у загальному вигляді. Недосконалість підходів до прийняття рішення для визначення ефективності розподілу рухомого складу, а саме 3 урахуванням наявності вагонів необхідної 
категорії придатності для перевезення заданої номенклатури вантажів та їх кількості, не дозволяє в повній мірі задовольнити заявки вантажовласників на перевезення. В існуючій системі замовлень на перевезення власник вантажу не має змоги додатково зазначити вимоги до необхідного технічного стану рухомого складу, що надається до навантаження.

Аналіз останніх досліджень i публікацій. Раціональна координація роботи елементів транспортно-логістичної системи залізниць, оптимальний перерозподіл між ними обсягів роботи, формування на цій основі інформаційної бази і підходів щодо прийняття обгрунтованих управлінських рішень $є$ однією 3 головних умов підвищення ефективності i якості функціонування залізниць України. Досягти цього можливо за рахунок використання складних методів, які у комплексі враховують інтереси перевізника, вантажовласника та інших учасників процесу доставки [1].

Питанням, пов'язаним із забезпеченням вантажовласників достатньою кількістю вагонів у повному обсязі, ефективністю розподілу транспортних ресурсів за рахунок розробки i удосконалення інформаційної системи певних АРM, а також пов'язаним 3 нестачею рухомого складу та несвоєчасним поданням вагонів під навантаження 3 причини низької пропускної спроможності станцій, приділяється значна увага у наукових працях [2-10].

Визначення мети дослідження. Завданням, покладеним в основу дослідження, $€$ удосконалення автоматизованої системи для забезпечення вантажовласників транспортними засобами відповідно до їх заявок за допомогою логістичних методів.

Основна частина дослідження. Існуюча автоматизована система документообігу замовлень на перевезення вантажів та формування планів (АС “МЕСПЛАН") призначена для автоматизації процесу формування замовлень, узгодження їх на рівні залізниці та Укрзалізниці, доведення результатів узгодження до вантажовідправника. АС “МЕСПЛАН" підтримує обмін замовленнями та результатами ї узгодження на експортні та транзитні перевезення із сусідніми адміністраціями.

$$
\text { АС “МЕСПЛАН" розроблена для }
$$
працівників планових відділів служби перевезень залізниці і ЦДП для автоматизації процесу введення замовлень на перевезення i подальшого формування планів. Також АC "МЕСПЛАН" дозволяє введення замовлень працівникам станцій, товарних контор, окремих вантажовідправників $з$ можливістю обмеження введення відповідно по коду станції відправлення, коду вантажовідправника.

Упродовж фази життя замовлення на перевезення формуються три пари даних по навантаженню:

заявлені об'єми (тонни і вагони); узгоджені об’єми (тонни і вагони); кореговані об'єми (вагони і тонни).

Основними параметрами для фільтрації списку заявок є: вид плану, вид перевезення, рід вагона, номенклатура вантажу, станція відправлення, залізниця відправлення, станція призначення, держава призначення, вага, кількість вагонів та ін.

Як видно 3 перерахованих вище параметрів, у замовленні на перевезення вантажовласник не має змоги додатково зазначити вимоги до необхідного технічного стану рухомого складу, що надається до навантаження.

Наступнй етап забезпечення відправників вагонами $\epsilon$ безпосередньою роботою 3 розподілу наявного порожнього рухомого складу. Розподілом транспортних ресурсів на полігоні Дирекції залізничних перевезень керує диспетчер-вагонорозпорядник (ДНЦВ). На основі наявної інформації про місце знаходження порожніх вагонів, їx кількість, потребу та інші фактори диспетчервагонорозпорядник виконує регулювання вагонопотоків, спираючись, в основному, на свій досвід роботи та інтуїцію. Виходячи з того, що висновки про найбільш імовірний технічний стан рухомого складу залежать від «людського фактора», враховуючи високий рівень зносу транспортних ресурсів, і те, що обгрунтовані методи визначення якості $\mathrm{i}$ придатності вагонів для перевезення певного виду вантажів не належать до вхідної інформації ДНЦВ, виникає ситуація можливої помилки при розподілі.

Питанням технічного стану вагонів присвячені розробки в галузі автоматизованої системи пономерного обліку, контролю дислокації, аналізу використання та регулювання вагонного парку на залізницях Росії (ДИСПАРК). ДИСПАРК створений за 
мети досягнення максимального прибутку залізниць за рахунок повного задоволення заявок вантажовласників на перевезення 3 мінімальними експлуатаційними витратами на їх забезпечення.

Складові ефективності системи: підвищення прибутку залізниць за рахунок досягнення максимального рівня завантаження відповідно до вимог вантажовласників; скорочення експлуатаційних витрат на переміщення вагонних парків за рахунок використання раціональних методів їх регулювання; покращення використання вантажопідйомності вагонів за рахунок раціонального їх відбору під навантаження вантажів; скорочення штрафів за перевищення строків доставки вантажів, а також плат за використання «чужих» вагонів; економія за рахунок автоматизованого контролю встановлених строків перевезення i знаходження на російських залізницях, виконання нормативів часу за елементами обігу вагонів та відхилень від встановленої технології перевезень; поетапне скорочення числа станційних працівників, що виконують облік операцій 3 вагонами, заповнення необхідної документації, розробку звітності та передачу відомостей, в цілому по залізницях Російської Федерації; створення передумов для укрупнення полігонів управління при мінімізації споживання ресурсів рухомого складу для виконання пред'явленого обсягу перевезень; скорочення витрат, пов'язаних 3 технічним обслуговуванням та ремонтом вантажних вагонів за рахунок впровадження нової технології управління цим процесом, в тому числі в залежності від обсягу роботи (пробігів), що виконаний конкретним вагоном.

Основними задачами управління вантажним парком є: аналіз розподілу вагонів на російських залізницях за будь-яким типом рухомого складу 3 зазначенням держав (підприємств)-власників вагонів та переліку російських залізниць (відділень, станцій), де вони дислокуються в даний момент часу; контроль часу находження вагонів інших держав на російських залізницях; аналіз порушень завантаження «чужих вагонів»; управління парком напіввагонів; управління парком цистерн; управління передаванням поїздів і вагонів; управління вагонами, що відчіплюються від транзитних поїздів; управління окремим вагоном; управління технічним станом вагонного парку.

В систему ДИСПАРК закладено принципово нову технологію управління ремонтом та технічним утриманням вагонів. Суть іiі полягає в тому, що планування всіх видів ремонту вантажних вагонів здійснюється не за часом, а в залежності від обсягу роботи, що виконується кожним вагоном. 3 цією метою по кожному вагону система веде облік виконання завантажених i порожніх вагонокілометрів, кількість навантажень i вивантажень, перероблень на сортувальних гірках. В залежності від цих факторів по вагону кожного типу повинні бути встановлені порогові значення обсягу виконаної вагоном роботи, після якого повинен бути проведений певний вид ремонту. Це повинно виключити існуючу нині практику, коли поставлення вагонів у ремонт здійснюється достроково. 3 інвентарю виключаються технічно справні вагони, а рухомий склад, наприклад відставлений в резерв i який не здійснив жодного кілометру пробігу, 3 закінченням терміну прямує в ремонт. За оцінками, виконаними спеціалістами Департаменту вагонного господарства ВАТ «РЖД», нова технологія призвела до скорочення потреби в ремонті вагонів на $20 \%$ [10].

Але ці розробки в більшій мірі присвячені питанням часу проведення певного типу ремонту, а не питанням забезпечення вантажовласника вагонами певного технічного стану.

Завданням, покладеним в основу дослідження, є удосконалення автоматизованої системи для забезпечення вантажовласників транспортними засобами відповідно до їх заявок за допомогою логістичних методів.

Поставлене завдання вирішується тим, що в автоматизовану систему додатково введений блок, який виконує визначення придатності рухомого складу під навантаження того чи іншого роду вантажу (за рахунок введення коефіцієнтів інтенсивності експлуатації), тим самим зменшуючи витрати, пов'язані із часом на проведення технічного та комерційного огляду вагонів, рівень відмов у забезпеченні клієнтів необхідним рухомим складом, покращуючи експлуатаційні показники роботи станції та рівень прибутковості Укрзалізниці в цілому. 
Модель інтегрується в інформаційну систему автоматизованого робочого місця маневрового диспетчера (АРМ ДСЦ), який, за потреби, передає інформацію диспетчерувагонорозпоряднику (ДНЦВ). Для цього на АРМ ДСЦ проводяться розрахунки зі встановлення коефіцієнтів інтенсивності експлуатації транспортних засобів, як складових зносу, необхідних для визначення рівня придатності рухомого складу для перевезення певного вантажу. Після отримання даних про наявний порожній рухомий склад інформація передається до ДНЦВ, який проводить декілька експериментів для визначення знаходження вивантажених порожніх вагонів необхідного технічного стану, передає розпорядження про проведення технічного і комерційного огляду тільки цих вагонів та переправляе їх до станцій навантаження визначеного вантажу. Рішення приймаються виходячи 3 мінімізації витрат часу на проведення технічного і комерційного огляду всіх вагонів у порівнянні 3 оглядом вагонів тільки необхідного стану, експлуатаційних витрат та потреби у парку вагонів для здійснення навантаження 3 мінімальним порожнім пробігом транспортних засобів.

Система управління транспортними ресурсами має цільову функцію

$$
\Phi_{\left(x_{i j k}\right)}=\sum_{i=1}^{\alpha} \sum_{j=1}^{\beta} \sum_{k=1}^{\gamma}\left(r_{i j} \omega_{k} x_{i j k}+x_{i j k} \Delta t_{i j} C_{i j}\right) \rightarrow \min
$$

при обмеженнях

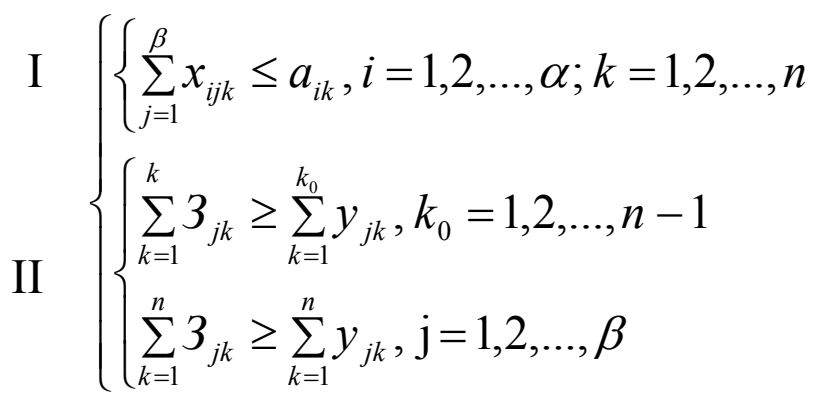

де $y_{j k}=\sum_{i=1}^{\alpha} x_{i j k}$;

$r_{i j}$ - відстань між пунктами формування та накопичення (елементи матриці $\mathrm{G}$ );

$\omega_{k}$ - вартість надання одного вагона відповідного типу та придатності на один кілометр;

$x_{i j k} \quad-\quad$ кількість вагонів категорії придатності к, що направляються з пункту Аі в пункт Вј згідно з відкоригованою заявкою.

$\Delta t_{i j}$ - економія часу на проведення ТО та КО при невідповідності категорії придатності вагона тій, що заявлена вантажовласником для певного вантажу

$$
C_{i j} \text { - питома вартість проведення КО та ТО }
$$
на одну годину.
Підсистема I забезпечує кількість, підсистема II забезпечує якість.

Дана модель відображає основні цілі системи для забезпечення вантажовласників транспортними засобами відповідно до їх заявок за допомогою логістичних методів, які сприятимуть:

- мінімізації порожнього пробігу транспортних засобів;

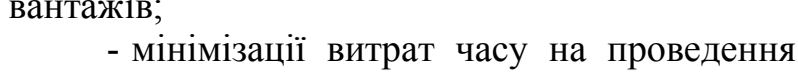

- збільшенню обсягів перевезених технічного і комерційного огляду;

- зниженню витрат палива й електроенергії;

- мінімізації експлуатаційних витрат та потреби у парку вагонів для здійснення навантаження.

Висновки 3 дослідження і перспективи, подальший розвиток у цьому напрямку. Запропонований метод виконання заявок, а 


\section{Експлуатація залізниць}

саме розподіл рухомого складу під навантаження та забезпечення ним, дозволяє проаналізувати можливість забезпечення вантажовласників необхідною кількістю транспортних ресурсів, 3 урахуванням перевезення певної номенклатури вантажу, 3 мінімальними витратами та максимальною можливістю схоронності вантажу. Рішення про варіант розподілу порожнього рухомого складу буде прийматися, виходячи $з$ того, що подача вагонів під навантаження повинна забезпечувати мінімальні витрати вагонокілометрів та забезпечення вантажовласників транспортними ресурсами належного технічного стану, який буде у наявності заздалегідь та в необхідному обсязі.

В перспективі пропонується формування нечіткої бази знань та системи підтримки прийняття рішення у підрозділах залізниць при розподілі рухомого складу.

\section{Список використаних джерел}

1. Панченко, С.В. Критерій якості ухвалення рішення по керуванню в складній ієрархічній системі [Текст] / Г.І. Загарій, С.В. Панченко, Б.Т. Ситнік, В.А. Бриксін // Інформаційно-керуючі системи на залізничному транспорті. - 2009. - №3. - С. 54-58.

2. Чеклов, В.Ф. Автоматизована система розподілу порожніх вагонів [Текст] / В.Ф. Чеклов, В.М. Чеклова, О.І. Шеховцов // Вісник ДІАТ. - 2008. - №2. - С. 13-18.

3. Ломотько, Д.В. Удосконалення функціонування автоматизованої системи розподілу транспортних ресурсів на Харківській дирекції залізничних перевезень [Текст] / Д.В. Ломотько, А.О. Ковальов, О.В. Ковальова // 3б. наук. праць Укр. держ. акад. залізнич. трансп. - Харків: УкрДАЗТ, 2013. - Вип. 137. - С. 5-10.

4. Ломотько, Д.В. Обгрунтування вибору та організації роботи системи формування составів поїздів. Практичний аспект [Текст] / Д.В. Ломотько, А.О. Ковальов, О.В. Ковальова // Восточноевропейский журнал передовых технологий. - 2013. - Вып. 4/3 (64). - С. 18-20.

5. Шеховцов, О.I. Розробка математичної моделі забезпечення порожнім рухомим складом спеціалізованих вантажних станцій [Текст] / О.І. Шеховцов // Вісник Донецької академії автомобільного транспорту. - 2011. - №2. - С. 28.

6. Котенко, А.М. Удосконалення інформаційної технології роботи 3 вагонами власності підприємств у АСК ВП УЗ [Текст] / А.М. Котенко, А.В. Кулешов, В.В. Кулешов // Зб. наук. праць. Харків: УкрДАЗТ, 2010. - Вип. 113. - С. 38-46.

7. Логистическое управление грузо- и вагонопотоками: Труды специалистов Украинской государственной академии железнодорожного транспорта [Текст]: колективна монографія // под ред. Д.В. Ломотько. - Deutschland: Palmarium Academic Publishing Saarbrucken, 2014. - 105 c.

8. Бутько, Т.В. Планування перевезень вантажу на основі раціональної організації вагонопотоків на залізниці із застосуванням теорії нечітких множин [Текст] / Т.В. Бутько, О.В. Лаврухін // СхідноЄвропейський журнал передових технологій. - 2004. - Спецвип. 7. - С. 16.

9. Ломотько, Д.В. До питання оптимізації розподілу рухомого складу під навантаження на залізничному полігоні [Текст] / Д.В. Ломотько, М.М. Кузнецов // Інформаційно-керуючі системи на залізничному транспорті. - 2005. - №4. - С. 96.

10. Елисеев, С.Ю. Оптимальное регулирование порожних вагонопотоков на железных дорогах России [Текст] / С. Ю. Елисеев // Актуальные проблемы управления перевозочным процессом. СПб.: ПГУПС, 2002. - С. 21.

11. Управление и информационные технологии на железнодорожном транспорте [Текст]: учеб. для вузов ж.-д. транспорта / Л.П. Тулупов, Э.К. Лецкий, И.Н. Шапкин, А.И. Самохвалов; под ред. Л.П. Тулупова. - М.: Маршрут, 2005. - 467 с.

Ломотько Денис Вікторович, доктор технічних наук, професор, кафедра транспортних систем і логістики, Український державний університет залізничного транспорту. Тел.: (057) 730-19-55, E-mail: den@kart.edu.ua. Ковальов Антон Олександрович, кандидат технічних наук, доцент, кафедра управління вантажною i комерційною роботою, Український державний університет залізничного транспорту. Тел.: (057) 730-10-85, Еmail: kovalovanton@mail.ru. 


\section{Експлуатація залізниць}

Ковальова Оксана Володимирівна, асистент, кафедра управління вантажною і комерційною роботою, Український державний університет залізничного транспорту. Тел.: (057) 730-10-85, E-mail:

oksanapesochin@mail.ru.

Denis Lomotko, d-r science professor, Department of Transport systems and logistics, Ukrainian State University of Railway Transport. Tel.: +38 (057) 730-19-55, E-mail: den@kart.edu.ua.

Anton Kovalov, lecturer, Department of Management of cargo and commercial work, Ukrainian State University of Railway Transport. Tel.: +38 (057) 730-10-85, E-mail: kovalovanton@mail.ru.

Oksana Kovalova, assistant, Department of Management of cargo and commercial work, Ukrainian State University of Railway Transport. Tel.: +38 (057) 730-10-85, E-mail: oksanapesochin@mail.ru.

Стаття прийнята 02.07.2015 p. 